\title{
First detection of Chlamydia trachomatis LGV biovar in the Czech Republic, 2010-2011
}

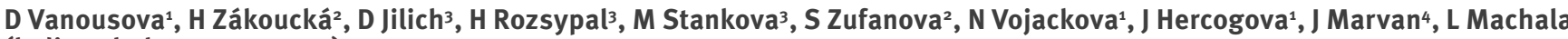
(ladimachala@centrum.cz) ${ }^{5}$

1. Department of Dermatovenereology, Second Faculty of Medicine, Charles University and University Hospital Bulovka, Prague, Czech Republic

2. National Reference Laboratory for Diagnostics of Syphilis and Chlamydia Infections, National Institute of Public Health, Prague, Czech Republic

3. Department of Infectious and Tropical Diseases, First Faculty of Medicine, Charles University and University Hospital Bulovka, Prague, Czech Republic

4. Department of Surgery, University Hospital Bulovka, Prague, Czech Republic

5. Department of Infectious Diseases, Third Faculty of Medicine, Charles University and University Hospital Bulovka, Prague, Czech Republic

Citation style for this article:

Vanousova D, Zákoucká H, Jilich D, Rozsypal H, Stankova M, Zufanova S, Vojackova N, Hercogova J, Marvan J, Machala L. First detection of Chlamydia trachomatis LGV biovar in the Czech Republic, 2010-2011. Euro Surveill. 2012;17(2): pii=20055.

Available online: http://www.eurosurveillance.org/ViewArticle.aspx?Articleld=20055

We present four cases of proctitis in HIV-infected men having sex with men (MSM) living in the Czech Republic. The causative agent in all cases was the lymphogranuloma venereum (LGV) biovar of Chlamydia trachomatis. The spread of proctitis caused by $C$. trachomatis serovars L1-3 among MSM has been observed in several European countries, the United States and Canada since 2003. To our knowledge, no LGV cases in eastern Europe have been published to date.

Between February 2010 and February 2011, four men who have sex with men (MSM) infected with human immunodeficiency virus (HIV), who were under regular observation for HIV infection at the Bulovka University Hospital AIDS Center in Prague, Czech Republic, developed symptoms of acute proctitis. The most prominent symptom in all four patients was intensive rectal pain lasting on average 10 days (range: 7-21 days). Other symptoms included blood in the stool or pinkish mucous discharge, constipation and tenesmus. Case 1 also had one enlarged, painful inguinal lymph node. Anoscopies were performed on Case 1 and Case 3 and revealed congested, irritated mucous membranes with a whitish coating. None of the patients had urethritis, fever, or other systemic symptoms (see Table).

To our knowledge, these cases are the first LGV infections detected in the region.

\section{Background}

Lymphogranuloma venereum (LGV) is a sexually transmitted disease (STD) caused by Chlamydia trachomatis serovars L1-3 [1]. Rare in industrialised countries, LGV is most often restricted to Africa, Asia, South America and the Caribbean [1,2]. Outbreaks of LGV proctitis in HIV-infected MSM have, however, been reported in several European countries, the United States and Canada [3-9]. Infections with LGV serovars, mainly L2, have been reported in North America and in Belgium, Denmark, France, the Netherlands, Portugal, Spain, the United Kingdom and Sweden, but to the best of our knowledge, there have been no publications to date reporting cases in eastern Europe.

\section{Clinical and behavioural information}

Three cases were regular visitors of gay clubs where they repeatedly had protected receptive anal intercourse with casual partners, but also used sex toys without condoms. One case reported having had unprotected anal sex and used sex toys with only one partner during the year before diagnosis. The identity and possible symptoms of the partner remain unknown to us. All but one of the cases were taking combination antiretroviral therapy (cART) and their mean $\mathrm{CD}_{4+}$ $\mathrm{T}$ cell count was $540 / \mu \mathrm{L}$ (range: $414-602 / \mu \mathrm{L}$ ). Their median age was 46 years (range: $39-47$ years) and the average time since the diagnosis of HIV infection was 27.75 months (range: 9-39 months). Three of them had already been treated for one episode of STD in the past (Table).

\section{Laboratory investigation}

Rectal swabs were taken from all cases for culture and PCR for Neisseria gonorrhoeae and for PCR for C. trachomatis (Cobas CT/NG, Roche). All cases were screened serologically for syphilis. The PCR tests for C. trachomatis were positive in all four cases. In Case 1, PCR was also positive for $N$. gonorrhoeae. The samples positive for $C$. trachomatis were stored at $-80^{\circ} \mathrm{C}$ for further identification of the LGV genotype, which became available in the Czech Republic in May 2011. 
The LGV genotype was identified by PCR amplification of a 262 bp fragment of target DNA using the dual-priming oligonucleotide primers (DPO) test. This method targets the $p m p-H$ gene and enables simultaneous detection of LGV-serovars and differentiation of L1-3 from other serovars [10].

\section{Treatment}

Therapy with oral azithromycin $1 \mathrm{~g}$ once per week for three weeks was started in Case 1, who had been concomitantly diagnosed with a $N$. gonorrhoeae infection. The anorectal symptoms resolved, but the lymph node abscessed and needed to be punctured. The puncture was also PCR-positive for $C$. trachomatis. A consecutive treatment with oral doxycycline, $100 \mathrm{mg}$ twice per day for five weeks, was started, with the enlarged lymph node eventually regressing after this therapy. The other three cases were treated with oral doxycycline, $100 \mathrm{mg}$ twice per day for 14 to 21 days, and in all of them the symptoms resolved during the therapy. The post-treatment rectal swabs for PCR of $C$. trachomatis were negative in all four patients. The Table summarises details of the patients' risk factors, clinical symptoms and therapy.

Table. Risk factors, clinical symptoms, therapy and sexually transmitted disease history of lymphogranuloma venereum cases, Czech Republic, February 2010 to February $2011(n=4)$

\section{Discussion and conclusions}

The Czech cases of LGV infection were very similar to the cases reported both in North America and western Europe [4]. All cases were HIV-infected MSM who used sex toys; three of them had had numerous sexual contacts. Furthermore, the clinical symptoms were very similar and their intensity corresponded to what is typical for LGV proctitis [11]. Although the method we used to identify LGV DNA cannot differentiate between L1, L2 and L3 genotypes, it distinguishes $\mathrm{L}_{1-3}$ from other serovars; the presence of the LGV infections in the region of eastern Europe is therefore evident.

The recommended therapy for LGV proctitis is oral doxycycline, $100 \mathrm{mg}$ orally twice per day for three weeks [12]. Two of our cases were treated with the recommended dose of doxycycline, but only for two weeks. This shorter regimen was chosen because the LGV aetiology was not known, as the method for the identification of LGV biovars was introduced in the Czech Republic in May 2011. Nevertheless, even the two-week therapy with doxycycline proved effective enough in our cases.

The increased frequency of identification of LGV serotypes of $C$. trachomatis in developed countries in recent years is certainly connected to the introduction of modern molecular diagnostic methods into routine practice; on the other hand, it also closely correlates with the rapid increase in the incidence of syphilis among MSM in the same regions, including the Czech Republic [13-15]. This situation probably demonstrates decreasing awareness on the part of MSM about the risk of transmission of STDs. The frequent use of sex toys among patients with LGV proctitis indicates that these objects may play an important role in the transmission of LGV biovars of $C$. trachomatis $[16,17]$.

This new epidemiological situation requires thorough analysis in order to adapt interventional strategies especially for population groups at particular risk such as HIV-infected MSM. Active case-finding and contact tracing for LGV infection should be included in routine healthcare for such high-risk populations.

In addition, the cases described here document that the spread of LGV strains of $C$. trachomatis has reached eastern Europe, and further reports of the identification of this pathogen in this region can be expected soon after the introduction of appropriate diagnostic methods in this region.

\section{TABLE}

Risk factors, clinical symptoms, therapy and sexually transmitted disease history of lymphogranuloma venereum cases, Czech Republic, February 2010 to February $2011(n=4)$

\begin{tabular}{|c|c|c|c|c|c|}
\hline Case & Risk factors & Symptoms & Therapy & Other STDs & cART \\
\hline 1 & $\begin{array}{l}\text { Protected sexual intercourse } \\
\text { with multiple sexual } \\
\text { partners, use of sex toys }\end{array}$ & $\begin{array}{l}\text { Rectal pain, constipation, } \\
\text { blood in stool, tenesmus, } \\
\text { unilateral inguinal painful } \\
\text { lymphadenopathy }\end{array}$ & $\begin{array}{l}\text { Azithromycin (1 g orally every } \\
\text { five days for three weeks); } \\
\text { doxycycline (100 mg twice } \\
\text { per day for five weeks) }\end{array}$ & $\begin{array}{l}\text { Coinfection with } \\
N . \text { gonorrhoeae, } \\
\text { syphilis in anamnesis }\end{array}$ & $\begin{array}{l}\text { Lopinavir/ritonavir + } \\
\text { zidovudin + lamivudin }\end{array}$ \\
\hline 2 & $\begin{array}{l}\text { Unprotected sexual } \\
\text { intercourse with a stable } \\
\text { partner, use of sex toys }\end{array}$ & $\begin{array}{l}\text { Rectal pain, constipation, } \\
\text { mucous discharge with } \\
\text { blood, tenesmus }\end{array}$ & $\begin{array}{l}\text { Doxycycline } \\
\text { (100 mg orally twice per day } \\
\text { for two weeks) }\end{array}$ & $\begin{array}{l}\text { Syphilis in } \\
\text { anamnesis }\end{array}$ & $\begin{array}{l}\text { Tenofovir + zidovudin } \\
\text { + lamivudin }\end{array}$ \\
\hline 3 & $\begin{array}{l}\text { Protected sexual intercourse } \\
\text { with multiple sexual } \\
\text { partners, use of sex toys }\end{array}$ & $\begin{array}{l}\text { Mucous pinkish stool, } \\
\text { constipation, tenesmus }\end{array}$ & $\begin{array}{l}\text { Doxycycline } \\
\text { (100 mg orally twice per day } \\
\text { for two weeks) }\end{array}$ & No & $\begin{array}{l}\text { Lopinavir/ritonavir } \\
+ \text { tenofovir }+ \\
\text { emtricitabine }\end{array}$ \\
\hline 4 & $\begin{array}{l}\text { Protected sexual intercourse } \\
\text { with multiple sexual } \\
\text { partners, use of sex toys }\end{array}$ & $\begin{array}{l}\text { Rectal pain, } \\
\text { mucous pinkish stool, } \\
\text { constipation, tenesmus }\end{array}$ & $\begin{array}{l}\text { Doxycycline } \\
\text { (100 mg orally twice per day } \\
\text { for three weeks) }\end{array}$ & $\begin{array}{l}\text { Gonorrhoea in } \\
\text { anamnesis }\end{array}$ & No \\
\hline
\end{tabular}

CART: combination antiretroviral therapy; STD: sexually transmitted disease. 


\section{References}

1. Mabey D, Peeling RW. Lymphogranuloma venereum. Sex Transm Infect. 2002;78(2):90-2.

2. Blank S, Schillinger JA, Harbatkin D. Lymphogranuloma venereum in the industrialised world. Lancet. 2005;365(9471):1607-8.

3. Kropp RY, Wong T; Canadian LGV Working Group. Emergence of lymphogranuloma venereum in Canada. CMAJ. 2005;172(13):1674-6.

4. Savage EJ, van de Laar MJ, Gallay A, van der Sande M, Hamouda O, Sasse A, et al. Lymphogranuloma venereum in Europe, 2003-2008. Euro Surveill. 2009;14(48): pii=19428. Available from: http://www.eurosurveillance.org/ViewArticle. aspx?Articleld $=19428$

5. Nieuwenhuis RF, Ossewaarde JM, Gotz HM, Dees J, Thio HB, Thomeer MG, et al. Resurgence of lymphogranuloma venereum in Western Europe: an outbreak of Chlamydia trachomatis serovar L2 proctitis in The Netherlands among men who have sex with men. Clin Infect Dis. 2004;39(7):996-1003.

6. Ward H, Martin I, Macdonald N, Alexander S, Simms I, Fenton $\mathrm{K}$, et al.: Lymphogranuloma venereum in the United Kingdom. Clin Infect Dis. 2007;44(1):26-32.

7. Herida M, de Barbeyrac B, Sednaoui P, Scieux C, Lemarchand N, Kreplak G, et al.: Rectal lymphogranuloma venereum surveillance in France 2004-2005. Euro Surveill 2006;11(9):pii=647. Available online: http://www. eurosurveillance.org/ViewArticle.aspx?Articleld $=647$

8. Castro R, Baptista T, Vale A, Nunes H, Prieto E, Mansinho $\mathrm{K}$, et al. Anorectal lymphogranuloma venereum: the first two confirmed cases in Portugal. Euro Surveill. 2008;13(50):pii=19060. Available from: http://www. eurosurveillance.org/ViewArticle.aspx?Articleld $=19060$

9. Cusini M, Boneschi V, Tanzi C, Girgenti V, De Vries H, Alessi E. Ano-rectal lymphogranuloma venereum: the first case in Italy. G Ital Dermatol Venereol. 2008;143(1):83-5.

10. Chen CY, Chi KH, Alexander S, Martin IM, Liu H, Ison CA, et al. The molecular diagnosis of lymphogranuloma venereum: evaluation of a real-time multiplex polymerase chain reaction test using rectal and urethral specimens. Sex Transm Dis. 2006;34:451-455

11. Hoie S, Knudsen LS, Gerstoft J. Lymphogranuloma venereum proctitis: a differential diagnose to inflammatory bowel disease. Scand J Gastroenterol. 2011;46(4):503-10.

12. McLean CA, Stoner BP, Workowski KA. Treatment of Iymphogranuloma venereum. Clin Infect Dis. 2007;44(Suppl 3):S147-52.

13. Savage EJ, Hughes G, Ison C, Lowndes CM. Syphilis and gonorrhoea in men who have sex with men: a European overview. Euro Surveill. 2009;14(47):pii=19417. Available from: http://www.eurosurveillance.org/ViewArticle. aspx?Articleld $=19417$

14. Zákoucká H, Polanecký V, Kastánková V. Syphilis and gonorrhoea in the Czech Republic. Euro Surveill. 2004;9(12): $\mathrm{pii}=496$. Available from: http://www. eurosurveillance.org/ViewArticle.aspx?Articleld=496

15. Kuklová I, Kojanová M, Zákoucká H, Pánková R, Velcevský P, Rozehnalová Z, et al. Dermatovenereology in the postcommunist era: syphilis in Prague during 1999 to 2005. Dermatol Clin. 2008;26(2):231-7.

16. O'Connor C, O'Connor MB, Clancy J, Ryan A. Sex toy hygiene. Int J STD AIDS. 2009;20(11):806-7.

17. Ronn MM, Ward H. The association between lymphogranuloma venereum and HIV among men who have sex with men: systematic review and meta-analysis. BMC Infect Dis 2011;11:70. doi: 10.1186/1471-2334-11-70. 